\title{
Det ydmygende gangstativ
}

\author{
En kognitiv tilgang til synsvinkelproblemet i narrativ fiktion
}

\author{
KRISTIAN TYLÉN
}

Et af den narrative fiktions mest interessante særtræk er dens komplekse udsigelsesstrukturer: relationerne mellem afsenderen, det sproglige udryk, "handlingen" og modtageren. Mens det i de fleste andre sproglige sammenhænge er indlysende, hvem der siger hvad, eller hvis synsvinkel noget er præsenteret fra, er det ofte svært at afgøre, hvem der i fiktionen orienterer forhold som synsvinkel og stemmeføring. Det er fx muligt at repræsentere et visuelt scenarium fra flere vinkler samtidigt, og $i$ nogle tilfælde kan vi helt ned $i$ den enkelte frase identificere adskillelige subjekter, som hver især er ansvarlige for dele af diskursens udtryk: scenariet er måske 'perciperet' af ét, men 'evalueret' af et andet subjekt.

Dette kan umiddelbart forekomme kompliceret og fortænkt, men faktum er, at vi i en ureflekteret læsning ofte vil opleve sådanne fortællestrukturer netop som selvfølgelige, graciøse og enkle: Vores bevidsthed synes indrettet til at producere og recipere denne slags komplekse strukturer. Jeg vil i denne artikel angribe nogle narratologiske aspekter af litteraturen i lyset af nyere kognitionsforskning. Narratologien er oprindeligt en klassisk strukturalistisk disciplin, men undergår i øjeblikket, ligesom en række andre humanistiske videnskaber, et paradigmeskifte.

Det synes oplagt, at fortælling som en urgammel menneskelig adfærd er funderet $i$ vores fælles kognitive og neurale arkitektur. Den væsentligste følge af det kognitive paradigmes anvendelse på narratologien er, at fokus flyttes fra alene at beskæftige sig med at isolere selve objektet - fortællingen - til i stedet at betragte fortællingen som en del af den kommunikative kontekst, hvori den indgår. Fra at have betragtet fortællingen som et produkt - et statisk objekt, som er lig summen af identificerbare delkomponenter - ser man nu i højere grad fortællingen som en kognitiv proces, i hvilken både afsender, modtager og den omgivende verden spiller en aktivt skabende rolle $\mathrm{i}$ forhold til betydningskonstruktionen (Jahn 2000: I). Fortællingens strukturelle lovmæssigheder søges således ikke forklaret som "egenskaber ved teksten", men i højere grad som "egenskaber ved de producerende og reciperende bevidstheder".

Jeg forteller, du ser...

Fortællingen har en interessant dobbeltnatur. Den er på den ene side en referentiel forestillingsverden: ved fortællehandlingen skabes en mental virtuel verden i modtagerens bevidsthed. Den kan være underlagt samme normer og regler, hvad angår sociale og fysisk kausale relationer, som vores egen verden, eller kan variere fra den ved eksempelvis magiske elementer, sjove væsener eller andre tidsdimensioner. Men samtidig er fortællingen en kommunikativ meddelelse. Afsenderen henvender sig til modtageren med den intention at dele et oplevet forløb, den referentielle indholdsverden, med modtageren. Fortællingen er således på én gang en model af verden og en kommunikativ meddelelse.

I den narrative fiktion, som jeg beskæftiger mig med her, er denne kommunikative situation imidlertid ligeledes "fiktiviseret", idet der ikke er et naturligt sammenfald mellem afsender og oplever. Den reale person/forfatter, der har produceret fortællingen, har ikke oplevet begivenhederne på sin egen 
krop i en ontologisk verden. Han starter med at opdigte en fortællesituation med en afsenderpersonlighed, som indlejres i diskursen og rapporterer de fiktive begivenheder som egne oplevelser til en ligeledes fiktiv modtager (se fx Fleischman 1990: I06). Der etableres således i fortællingen endnu et referentielt rum, hvor en afsender (eller fortæller) fortæller en modtager om "noget, som er hændt". Jeg vil i det efterfølgende referere til disse to grundlæggende aspekter af fortællingen som henholdsvis det narrative og det diskursive.

Fortællingens udtryk kan således det ene øjeblik bevidstgøre os om det diskursive aspekt, som når fortælleren forlader fortællingens indholdsverden for at henvende sig direkte til modtageren eller reflekterer over selve fortællehandlingen, ligesom den det næste øjeblik kan lade os glide helt ind i det narrative rum, så vi glemmer fortælleren og snarere synes at se, hore, lugte eller fole den fortalte indholdsverden. Vi konceptualiserer således fortællingens udtryk efter graden af fortællerens 'tilstedeværelse' $i$ fortællingen. Dersom selve diskursen tiltrækker sig opmærksomhed, vil der være en tendens til, at vi oplever fortællingen netop som fortalt: Fortællingens ord bliver en slags orale auditive signaler, fremsagt af en fortællerstemme for modtagerens 'indre øre'. Dette ses i følgende passage fra Gogols fortælling Kappen:

I departementet for... nej, det er nok bedst ikke at røbe i hvilket. Der findes ikke mere prikne mennesker end embedsmænd, ligegyldigt om de er ansat i departementer, kancellier eller i hæren. I vore dage opfattes en nok så lille personlig krænkelse som et angreb på hele standen (Gogol u.år: I3).

Nok er der i passagen referencer til rumligt-visuelle størrelser, men vores oplevelse af passagen synes alligevel først og fremmest at være af en oral-auditiv karakter. Passagen fremkalder med andre ord ikke egentlige visuelle forestillinger om forholdene i den fortalte verden i så høj grad som forestillinger om selve fortællesituationen, fortællerens stemme og relation til begivenhederne. Udtryk som "nej, det er nok bedst ikke at røbe..." er en slags direkte tale, som ekspliciterer det kommunikerende individ, og dermed fortællingens meddelelsesaspekt.
Men som nævnt kan diskursen til andre tider være helt eller delvist usynliggjort i fortællingens udtryk. Dersom fortælleren ikke på noget tidspunkt vender opmærksomheden mod sig selv, sin egen fortælling eller tilhøreren, vil denne kommunikative kontekst udviskes. I stedet udfoldes fortællingens indholdsverden som oplevede, perceptuelle indtryk for modtagerens 'indre øje'. Modtageren glemmer fortællerens stemme og føler sig nærmest til stede i de rum, som skabes af fortællingen: fra at være tilhører bliver han/hun tilskuer (Brandt 2000: 3).

Der er imidlertid en væsentlig asymmetri i afsender og modtagers adgang til fortællingens indholdsverden. Modtageren er begrænset $i$ sin orientering og bevægelsesfrihed. Som modtager af en fortælling vælger vi ikke selv den vinkel, hvorfra vi observerer personer og begivenheder $\mathrm{i}$ den fortalte verden. $\mathrm{Vi}$ kan ikke selv beslutte lige at smutte om bag ved stakittet for at se, om den onde skurk skulle gemme sig dér. Vi kan heller ikke snuse ind og afgøre hvilken parfume den lækre sild bruger, hvis ikke afsenderen gør det for os. Modtageren ligger med andre ord under for en særlig orientering af opmarksomheden i den fortalte indholdsverden.

Afsenderen er i denne sammenhæng kendetegnet ved en dobbeltrolle. I modsætning til modtageren kender han/hun forløbet og de implicerede personer, objekter og rum. For afsenderen fremstår fortællingen som et blottet hele. For denne er der ikke noget uventet i begivenhedsforløbet, han/hun kender slutning, pointe m.v. ${ }^{\mathrm{I}}$

I dette dynamiske forhold mellem at opleve (prospektion) og at vide (retrospektion) ligger et vigtigt aspekt af fortællingens iboende teatralitet eller performance. I modsætning til eksempelvis en politirapport er det ikke altid fortællerens opgave at præsentere læseren/tilhøreren for "de nøgne facts". Fortællingen skal på en anden måde end rapporten retfærdiggøre sin egen eksistens, eksempelvis ved at have en vis underholdningsværdi, der kan fastholde modtagerens opmærksomhed (Fleischman 1990: I03). Fortællingens job er således snarere at "genopføre" begivenhedsforløbet på en levende måde, således at læseren bringes tæt på begivenheder og karakterer. En fortælling, fiktion eller fakta, er såle- 
des i sin natur en iscenesættelse af et forløb, der allerede har fundet sted.

Vi ser ofte begge sider af denne dobbeltnatur materialiseret $\mathrm{i}$ orienteringen af opmærksomhed $\mathrm{i}$ fortællingens narrative rum. Opmærksomhedsorienteringen kan således netop give udtryk for afsenderens principielt ubegrænsede viden om den fortalte indholdsverden, ligesom den kan tilbageholde denne viden for at lade modtageren opleve den fortalte verden sammen med personerne $i$ fortællingen.

\section{Perception, epistemiske strukturer og valorisering}

Det, jeg i denne sammenhæng har valgt at kalde opmarksomhedsorientering, er således udtryk for det, som ofte kaldes synsvinkel eller perspektiv. Disse termer har bestemt deres berettigelse $i$ analysen af fortællingens visuelt perceptuelle elementer. Imidlertid anvendes de ofte $\mathrm{i}$ en meget bred metaforisk betydning, hvor alt, lige fra den temporale organisation til spørgsmålet om fortællingens evaluerende elementer, bliver et spørgsmål om "hvem, der ser historien" (Jahn I999: 2). Dermed sløres vigtige nuancer. Med termen 'opmærksomhed' søger jeg således at ramme nogenlunde samme betydningsmæssige bredde, men samtidig undgå alt for megen metaforisk forvirring.

Modtagerens oplevelse af fortællingens indholdsverden fremstår, som jeg har været inde på, primært som en visuel perceptuel størrelse. På baggrund af afsenderens sproglige rapport forestiller modtageren sig, hvordan den fortalte verden ser ud og eventuelt hvilke lyde, lugte og følelsesindtryk den indeholder, som det er tilfældet $i$ følgende passage fra Lev Tolstojs lille fortælling “Tre Dødsfald”:

Et øjeblik var alt stille, men atter svajede træet, atter hørtes et smæld i dets stamme, og det styrtede med trætoppen mod den fugtige jord, mens dets grene knækkede og faldt af. [...] Rødkælken gav et fløjt og flagrede højere op. En gren, som den havde strejfet med sine vinger, gyngede et øjeblik og stivnede så med alle sine blade, som de andre (Tolstoj I997: 24-25).

Men som oftest indeholder fortællingens indholdsverden ligeledes elementer, der ikke er af perceptuel natur. Der kan til fortællerpersonligheden og karaktererne knytte sig visse mentale, epistemiske forhold som viden, ræsonnementer og refleksioner, som ikke umiddelbart opleves perceptuelt:

I lejrene og fængslerne var Sjukov blevet uvant med at lægge planer om, hvad der skulle ske i morgen eller om et år, og hvad han skulle ernære sin familie med. Ledelsen tænkte for ham i et og alt, det var ligesom lettere (Solzjenitzyn I963: 42).

Passagen refererer således ikke en særlig oplevelse af et forløb, der "udspiller sig for modtagerens øjne", i så høj grad som den er en mental reflekteren, der snarere fremstår for modtageren som en slags indirekte indre monolog (jf. $\mathrm{fx}$ frasen "det var ligesom lettere", der tydeligt er talesprog).

Dertil kommer, at der i fortællinger ofte vil forekomme udtryk af emotionel og valoriserende karakter. Modtageren møder med andre ord sjældent den fortalte indholdsverden som rå og uforarbejdede sansedata. Beskrivelsen af den fortalte verden vil således altid være præget af det observerende individs etiske, æstetiske og emotionelle tilstand, om end dette individ ikke er en navngivet, ekspliciteret karakter i fortællingen. Disse træk ses i følgende beskrivelse, der ved siden af gengivelsen af de visuelle indtryk - udtrykker en affektiv, empatisk evaluering af disse indtryk:

Hendes mund fortrak sig med et grædende udtryk som hos ganske små børn, når de bliver forskrækkede og med gråden i halsen stirrer på det, der har gjort dem bange. Denne stakkels Lizaveta var i den grad enfoldig, forkuet og i bund og grund forskræmt, at hun ikke engang løftede hænderne over hendes hoved. Hun gjorde bare en svag bevægelse med den frie venstre arm som for at skubbe ham fra sig (Dostoevskij I952: 88).

Mens sætningerne "hendes mund fortrak sig med et grædende udtryk" og "hun gjorde bare en svag bevægelse med den frie venstre arm" er udtryk for en registrering af faktiske visuelle indtryk fra den fortalte verden, synes sammenligningen med forskrækkede små børn at være udtryk for det beskuende individs personlige affektive oplevelse af scenariet. De efterfølgende adjektiver "stakkels", "enfoldig" og "forkuet" er på samme måde snarere evaluerende end registrerende, ligesom udtrykket " $i$ den grad 
[...] at hun ikke engang" fortæller os noget om den beskuendes forventning til en almindelig menneskelig reaktion. Skønt der i passagen ikke er en ekspliciteret observerende personlighed, kommer denne alligevel til udtryk i de evaluerende elementer. Den noget følelsesladede passage efterfølges imidlertid af en fuldstændig neutral beskrivelse af det videre begivenhedsforløb:

Øksehugget ramte hende med skarpen midt på kraniet og spaltede hele den øverste del af panden, næsten op til issen. Hun styrtede om (Dostoevskij 1952: 88).

Her gengives kun de rene visuelle indtryk - med nærmest kynisk præcision. Vægten ligger på detaljer i det faktiske scenarium, og der spores ingen empati eller emotionel affekt hos den beskuende.

Man kunne således foreslå en skala dækkende et kontinuum fra dyb indlevelse og affekt til den helt rene og uengagerede registrering af perceptuelle data. ${ }^{2}$ I så fald ville de to Dostoevskij-eksempler over for kunne repræsentere skalaens yderpunkter. En sådan skala er relevant, men vil imidlertid kun kunne gøre rede for en meget begrænset del af problematikken - for eksempel forekommer øksemordet os særligt makabert, netop fordi det beskrives så nøgternt. Det, der ved første øjekast ligner en helt værdineutral beskrivelse, synes således at være langt mere ekspressiv end den foregående værdiladede passage, fordi der hersker en udtalt divergens mellem scenariets grufulde indhold og den følelseskolde oplevelse af det, der kommer til udtryk i valoriseringen af scenariet.

Lidt forenklet kan vi således sige, at modtagerens adgang til fortællingens mentale indholdsverden går gennem disse tre konceptuelle elementer, eller opmærksomhedstyper (frit efter Jahn 1999: 4):

Perception: registrering af sanseindtryk, herunder ligeledes perception af mentale rum; fantasi, forestilling, erindring og drømme.

Epistemiske strukturer: viden, interpretation, argumentation, tankevirksomhed og intention.

Valorisering: affekt, empati, følelsesmæssig neutralitet, fremmedgjorthed, fortrolighed.
Vi møder sjældent disse tre elementer isoleret. Ofte vil registreringen og valoriseringen af perceptuelle data være svært adskillelige, ligesom det i mange tilfælde vil være svært at afgøre, hvorvidt der er tale om en beskrivelse af et perceptuelt scenarium eller en rapportering af en forudgående viden hos en fortæller. Når denne tredeling alligevel har sin berettigelse hænger det sammen med spørgsmålet om, hvem der orienterer opmærksomheden i fortællingen.

\section{Det opmarksomhedsorienterende subjekt}

Den narrative fiktions særlige udsigelsesstruktur er speciel derved, at den ofte synes at have en mangfoldighed af opmærksomhedsorienterende subjekter. De forestillingsbilleder, informationer og emotioner, som løbende fremkaldes i modtagerens bevidsthed, er således produkt af ét eller flere oplevende, reflekterende og evaluerende subjekter i fortællingen, som hver især har adgang til forskellige dele af den fortalte verden.

Et sådant opmærksomhedsorienterende subjekt kan være en manifesteret, navngivet karakter i den fortalte indholdsverden. Det særlige perspektiv og fokus, som vi som modtagere har, samles således i denne lokaliserbare figur, som det sker i følgende passage fra Bulgakovs Skabnesvangre $\mathrm{Eg}$ :

En grälig, olivenfarvet bjæalke rejste sig op fra vildnisset og voksede for øjnene af ham. Aleksandr Semjonovich mente at kunne se nogle gule, fugtige pletter, der var strøet hen over bjalken [...] Som den ragede op dér foran Aleksandr Semjonovich, mindede den ham, hvad højden angår, om en lygtepæl i Moskva, men blot tre gange tykkere, og meget smukkere på grund af den skælagtige tatovering (Bulgakov I989: 87).

Her er det tydeligt, at både de perceptuelle data, ræsonnementer og valoriseringer orienteres af $\mathrm{ka}-$ rakteren Aleksandr Semjonovitj. Hans placering i scenariet indskrænker hans synsfelt således, at ikke alt er tilgængeligt for ham, og dermed heller ikke for modtageren. Det viser sig nemlig senere, at det han ser, er en kæmpeslange.

I andre tilfælde kan det imidlertid ikke lade sig afgøre, præcis hvorfra et scenarium anskues, eller hvem der ser. Det opmærksomhedsorienterende 
subjekt er således reduceret til et eller flere punkter i den fortalte verden, som synes at hænge frit i luften uden at være bundet til nogen fysisk entitet. Jævnfør følgende beskrivende passage:

Morgenen var nu brudt helt frem, og en gylden stribe strøg hen over instituttets cremefarvede indgang, da professoren rejste sig fra mikroskopet og på sine sovende ben gik hen til vinduet (Bulgakov I989: I3-I4).

Her er det tydeligt, at det ikke er gennem professorens øjne, at vi betragter scenariet. Han opholder sig $i$ et lokale inde $i$ instituttet og kan således ikke se, hvordan solen "stryger hen over instituttets indgang”. Synsvinklen skifter $i$ anden halvdel af passagen fra en position uden for instituttet (fra hvilken instituttets yderside med indgangen er synlig) til en position indenfor, fra hvilken lokalets interiør med mikroskop og professor er synligt. Denne type orientering af perceptionen kan trods sin immaterialitet give udtryk for en række almindelige menneskelige mentale dispositioner såsom evaluering/affekt, forventning og intention, hvilket făr Talmy til at kalde synsvinklen "a type of individual" (Talmy 20oob: 443). I andre terminologier vil man typisk tilskrive en sådan synsvinkel fortællerpersonligheden: Fortælleren er således på én gang et talende subjekt i kommunikationens rum, men har samtidig ansvaret for den tilsyneladende subjektsløse perception $\mathrm{i}$ fortællingens indholdsverden.

Spørgsmålet om synsvinklens eller det perceptionsorienterende punkts placering synes væsentligt sværere at fastslå $\mathrm{i}$ det sidste eksempel. På baggrund af det særlige udsnit af den fortalte verden, der er $i$ fokus, kan vi afgøre en omtrentlig placering af synsvinklen. Måske ikke til et punkt, men til et område i den fortalte verdens rum. I andre tilfælde synes det slet ikke muligt at afgøre fra hvilken vinkel, scenariet perciperes. Et fokus i den fortalte verden behøver således ikke at have sin oprindelse i ét opmærksomhedsorienterende punkt. En beskrivelse af et scenarium kan således være funderet $i$ en hurtigt skiftende synsvinkelposition eller endog fra flere vinkler samtidigt (Talmy 200ob: 44I). Jævnfør således følgende passage fra Saramagos En Fortelling om

\section{Blindhed:}

Med foden på koblingen holder de utålmodige bilister deres biler på spring, de rykker frem, trækker sig tilbage, lige så nervøse som heste der aner pisken komme susende gennem luften (Saramago 1999: 7).

Skønt der i eksemplet stadig er tale om en registrering af perceptuelt visuelle data, er det meget vanskeligt at afgøre synsvinklens position. Vi befinder os på én gang både inde $\mathrm{i}$ bilerne, hvor vi kan se "foden på koblingen" (og der er ikke tale om én fod på én kobling, men snarere en masse fødder, på en masse koblinger - et billede af hvad der foregår $i$ alle bilerne), og udenfor, hvor bilernes rykken frem og tilbage giver anledning til sammenligningen med hestevæddeløb. Scenariet er således beskrevet fra flere vinkler samtidig: dels indefra, dels fra en ubestemmelig position uden for bilerne.

I eksemplerne ovenfor har vi således bevæget os fra det distinkte, definerbare og perceptionsorienterende subjekt mod en stadig mere abstrakt fundering af perceptionen. I det sidste tilfælde har vi således stadig et distinkt fokus (bilernes in- og eksteriør), mens det/de perceptionsorienterende subjekt(er) synes stort set umuligt at bestemme. Vi har dog stadig en oplevelse af at blive præsenteret for visuelt perceptuelle indtryk: at scenariet er et produkt af en perception fra flere vinkler. Abstraktionen fra det perceptionsorienterende subjekt kan dog også realiseres i sin absolutte form: det "perspektivløse” scenarium. Her præsenteres modtageren stadig for visuelt tilgængelige forhold, men uden at disse fremstår som egentlige perceptuelle oplevelser. Dette er fx tilfældet i den indledende passage til fortællingen "Avispapirbyen":

Der var engang en by hvor alting var lavet af avispapir. Gaderne, træerne og blomsterne var af avispapir. Alt var af avispapir. Man klædte sig i avispapir, spiste avispapir og sov i senge af avispapir (Adolphsen I996: 33).

I denne passage handler det ikke om, hvordan noget opleves, men hvordan noget er. Byen ser ikke $u d$ til at være lavet af, men er lavet af avispapir. Vi præ- 
senteres således for en række faktuelle, generiske egenskaber ved byen, som er uafhængige af enhver form for subjektive perspektiver og oplevelser. Vi har med andre ord stadig et fokus, men ingen perceptionsorienterende punkter, subjekter eller synsvinkler.

I takt med denne gradvise 'udvislning' af det lokaliserede, perciperende subjekt opleves de perceptuelle ind ryks subjektivitet som aftagende. Mens det første eksempel med Aleksandr og slangen var en beskrivelse af en umiddelbar og uinterpreteret oplevelse af et scenarium, har vi i sidste eksempel med avispapirbyen ikke en beskrivelse af en oplevelse af i så høj grad som en sandhed om avispapirbyen, formidlet af et vidende subjekt.

Mens subjektiviteten kan opleves som aftagende i takt med abstraktionen fra det perciperende subjekt, er det ikke nødvendigvis sådan, at den verden, der tegnes fra den superabstrakte synsvinkel, er udtryk for sandheden om den fortalte verden. Det kan stadig være en lokal virkelighed, der beskrives, for eksempel protagonistens handlingssfære, mens andre væsentlige forhold, som ikke har direkte berøring med denne, er udeladt. Dette kan eksempelvis ses i nogle psykologiske fortællinger. I disse fortællinger påvirker en forskydning $i$ en karakters mentale udrustning karakterens interpretation af sine reale omgivelser. Den verden, der fremstår for karakterens øjne, er således en blanding af virkelighed og mentale forestillinger, uden at karakteren er i stand til at skelne. Orienteres perceptionen samtidig af karakteren og med høj grad af abstraktion, bliver karakterens virkelighed også modtagerens: modtageren har altså ikke mulighed for at afgøre, hvilke elementer der er virkelige, og hvilke der er produkt af karakterens mentale forskydning.

Et eksempel på en sådan struktur finder vi i Dostoevskijs Dobbeltgangeren. Her forbliver synsvinklen 'trofast' mod protagonisten, hr. Goljadkin, som oplever de særeste ting. Samtidig er den i mange passager vendt bort fra protagonistens lokale synsvinkel, hvilket făr de irreelle forekomster til at fremstå som objektive sandheder i modtagerens øjne, som det ses i følgende passage, hvor hr. Goljadkin forfølger sin dobbeltgænger hjem til sin egen bopæl: Hr. Goljádkin ilede efter ham. Trappen var mørk, fugtig og snavset. Foran alle dørene stod køkkenspande, husgeråd eller forskelligt skrammel, og en fremmed, som for første gang og tilmed i mørke, steg op ad denne trappe, måtte være en evighed om at bestige den, udsatte sig hvert øjeblik for at brække benene og forbandede sædvanlig ikke blot trappen, men også sine bekendte, der kunne slå sig ned i en så ubekvem og vanskeligt tilgængelig bolig. Imidlertid - hr. Goljadkins ukendte følgesvend syntes at være fuldt ud fortrolig med alle trappens egenheder: han ilede opad med den største lethed uden at tøve et øjeblik, som var han hjemme hér og kendt med hvert trappetrin i huset. - Hr. Goljadkin var lige ved at indhente ham et par gange slog den ukendtes frakkesøm mod hans næse (Dostoevskij 1996: 58).

Skønt passagen er observeret og fortalt udefra, og intet umiddelbart indikerer, at der er tale om andet end en virkelig situation, antydes det snart, at dobbeltgængeren er et produkt af hr. Goljadkins tiltagende neurose, dvs. er en irreel figur, som kun eksisterer $\mathrm{i}$ hans bevidsthed og oplevelse af omgivelserne. Den virkelighed, som modtageren præsenteres for, er således, på trods af dens tilsyneladende objektivitet, hr. Goljadkins subjektive virkelighed, som er dybt påvirket af hans mentale tilstand. 3

Eksemplerne har indtil nu fortrinsvis beskæftiget sig med den del af opmærksomhedsorienteringen, som har med perceptionen at gøre. Noget lignende gør sig imidlertid gældende for de andre 'opmærksomhedstyper', præsenteret ovenfor. Den fiktive narrations epistemiske udsagn kan på samme måde være fjernet fra sin egentlige subjektive oprindelse. Jævnfør således følgende to fraser: "Hun var en af de smukke og bedårende unge piger, der som ved en fejltagelse af skæbnen er kommen til verden $i$ en embedsfamilie" (De Maupassant I903-I2: I45). "Det var en lille by, værre end en landsby, og næsten udelukkende befolket med gamlinge, der døde så sjældent, at det endog var fortrædeligt" (Tjekhov 1977: 297). Begge indleder de en fortælling. Den første Guy de Maupassants "Smykket", den næste Anton Tjekhovs "Rotsjilds Violin". I begge tilfælde synes vi at høre en alvidende fortællerstemmes præsentation af henholdsvis en person og en scene.

Ved nærmere bekendtskab med de Maupassants lille fortælling bliver det dog klart, at den ind- 
ledende frase snarere er udtryk for protagonistens, Mathildes, egen mening om sin situation. Det er tydeligvis hende, der finder det skæbnesvangert, at hun ikke er født ind $i$ aristokratiske kredse, nu da diamanter klæder hende så godt. Fortællingen spiller netop på hendes romantiserede forestilling om tilværelsen $i$ "de fine kredse": Da hendes mand endelig skaffer dem en invitation til et herskabeligt selskab, låner hun en meget fin diamanthalskæde af en velbjerget veninde. Festen er en stor succes, men da de når hjem, er halskæden væk, tabt på vejen hjem. De beslutter sig for at hemmeligholde det pinlige tab af halskæden og låner med møje og besvær penge til at indkøbe en ny diamantkæde som erstatning for den gamle. De næste ti år må de begge arbejde hårdt for at kunne tilbagebetale lånet. En dag møder hun tilfældigt sin rige veninde og beslutter at fortælle hende om det uheldige tab af halskæden. Veninden må imidlertid fortælle hende, at den halskæde, hun lånte, blot var en billig kopi.

De Maupassants fortælling er ikke psykologisk i den forstand, at vi indvies i karakterernes mentale virksomhed, tankerækker og overvejelser. Når modtageren alligevel er i stand til at danne sig et billede af karakterernes personligheder, er det fordi disse epistemiske aspekter stadig i nogen grad er til stede, men bortabstraheret fra deres egentlige subjektive oprindelse. Vi møder dem således 'afspejlet' i fortællerens kommentarer. Indirekte bliver fortællingens karakterer således opmærksomhedsorienterende subjekter.

Noget lignende gør sig gældende i passagen fra Tjekhovs fortælling "Rotsjilds Violin". Historiens hovedperson er den gamle og bitre Jakov Ivanov, som ernærer sig ved at bygge kister. Tjekhovs fortællestil er, som de Maupassants, enkelt skildrende: en gennemgående fortællerstemme beretter om begivenheder og personer udefra (i tredje person), tilsyneladende uden at vi 'kryber ind i' karakterernes bevidstheder. Det er imidlertid næppe denne tilfældige fortæller, der finder det "endog fortrædeligt", at så få mennesker dør i den lille landsby - dette er snarere udtryk for den gamle kistemagers holdning til sine omgivelser. Igen synes diskursen altså at være delvist orienteret af protagonisten, via en slags "indirekte indre monolog".
I de to eksempler fra henholdsvis de Maupassant og Tjekhov kan vi således iagttage, hvordan orienteringen af fortællingens epistemiske aspekt, ligesom perceptionen, dels kan fjernes fra subjektet, dels kan skifte mellem flere subjekter inden for et enkelt narrativt udsagn. Vender vi nu blikket mod den tredje opmærksomhedstype, nemlig valoriseringen, bliver billedet ikke mindre kompliceret.

På samme måde, som det er tilfældet med perceptionen og de epistemiske udtryk, kan valoriseringen bortabstraheres fra det valoriserende individ, så det er vanskeligt at afgøre, hvem der orienterer denne del af opmærksomheden $i$ en fortælling. Mens vi umiddelbart ville forvente, at perception og valorisering følges ad, at det iagttagende subjekt også er det, der evaluerer de indkomne sansedata, er det i fiktiv narration ikke altid tilfældet. Her forekommer det, at de to opmærksomhedstyper samtidigt orienteres af forskellige subjekter i fortællingen. Orienteringen af valoriseringen kan ligeledes skifte mellem flere subjekter, oven i købet inden for samme sætning, som det ses i følgende eksempel fra Peter Adolphsens lille fortælling "Et Kioskeventyr":

Bag et ydmygende gangstativ gik den mavesure gamle støder Paul Hahrt, uanfægtet af solskinsvejret, ned til kiosken efter avisen (Adolphsen 2000: 13).

Synsvinklen synes her at være placeret uden for protagonisten. Vi observerer denne, mens han bevæger sig ned til kiosken. På samme måde synes sætningens evaluerende udsagn "uanfægtet" og "mavesur" at være udwryk for en valoriserende instans uden for protagonisten, sandsynligvis historiens fortæller. "Mavesur" kan selvfølgelig henvise til protagonistens reale, helbredsmæssige tilstand, men opleves i denne sammenhæng snarere som et karaktertræk ved protagonisten. Prædikatet "uanfægtet" fortæller os, at fortælleren havde en anden forventning, nemlig at en sur gammel mand ville tøve med at gå ud i solskinsvejret. Men adjektivet "ydmygende" synes ikke at være udtryk for en fortællerinstans' evaluering af gangstativet i så høj grad som protagonisten, Paul Hahrts. Det er snarere ham, som finder gangstativet ydmygende. Dertil kommer 
prædikatet "gamle støder". Det lugter lidt af kammeratlig værtshusjargon. En "gammel støder" vil typisk være en, man drikker fadøl og spiller dart med. Der synes dog ikke at være baggrund for at formode, at der hersker den slags personlige relationer mellem fortæller og protagonist. Omvendt må der være nogle, for hvem Paul Hahrt er en gammel støder. Der må være et eller flere subjekter, der ligesom protagonisten er at finde $\mathrm{i}$ fortællingens indholdsverden, og hvis valoriserende prædikater refereres i frasen. Mens synsvinklen således synes stabil, flakker valoriseringen af de perciperede data i denne korte passage rundt mellem protagonist, fortæller og andre impliciterede subjekter i protagonistens omgivelser.

Noget lignende finder vi i følgende eksempel, hvor synsvinklen igen er hos en bortabstraheret fortæller, mens valoriseringen skifter mellem denne og en lokal karakter i den fortalte indholdsverden:

Sporvognenes brogede lys spejlede sig i laboratoriets vinduer, og højt oppe, ved siden af Kristusdomens tunge hue, kunne man se det matte, blege månesegl. Men hverken dette eller Moskvas forårsalarm trængte ind i professorens bevidsthed. Han sad på sin nymodens, indstillelige kontorstol og drejede med sine tobaksbrune ingre på indstillingsskruen til sit fremragende Zeiss-mikroskop, hvori var anbragt et almindeligt, ufarvet præparat af friske amøber (Bulgakov 1989:II).

Scenariet er således set udefra. En ikke-manifesteret fortæller registrerer en række visuelle indtryk, som ikke er sammenfaldende med professorens: "sporvognenes lys", "Kristusdomen" og professorens "tobaksbrune fingre" er forhold, som er uden for professorens synsvinkel (han kigger i mikroskopet). Samme fortællerpersonlighed giver også udtryk for en evaluering af disse indtryk. Lyset beskrives som "broget", Kristusdomens bue som “tung”, og måneseglet som "mat" og "blegt”. Men som fokus bevæger sig over på laboratoriets interiør, synes valoriseringen af disse indtryk at skifte, og det er således næppe det perciperende subjekt (fortælleren), der synes, at kontorstolen er "nymodens", og mikroskopet er "fremragende"; dette er snarere udtryk for professorens valorisering af disse forhold.
Mens perceptionen således fortsat orienteres af en observerende fortæller, er valoriseringen af synsindtrykkene nu hos den lokale figur, professoren. Kort efter synes dette forhold dog inverteret. Mens perceptionen nu orienteres af professoren, ligger evalueringen af synsindtrykkene tydeligvis ikke hos denne, men hos en ikke-manifesteret fortæller:

Aldeles fortræffeligt, sagde Persikov, kastede sig over mikroskopet og pressede sit højre øje mod okularet. Der var åbenbart noget overordentligt interessant at iagttage i frøens kråse, hvor man ganske tydeligt kunne se de livlige blodlegemer pile kækt af sted langs årernes flodarme (Bulgakov I989: I2).

Ordet "åbenbart” er her udtryk for, at det evaluerende subjekt ikke selv ligger inde med den fornødne tekniske viden til at vurdere de indtryk, han har adgang til gennem professorens øje, men må formode, at det er interessant på baggrund af fagfolkenes reaktion.

Det simple og det dybe

Som det er blevet tydeligt, er spørgsmålet om, hvem der orienterer opmærksomheden $\mathrm{i}$ den fortalte indholdsverden ikke kun et spørgsmål om at registrere synsvinkelskift mellem fortæller og karakterer. Det er ikke tilstrækkeligt at angribe analysen af den narrative diskurs som et spørgsmål om, hvem der ser historien. Samme fortællende passage kan have flere opmærksomhedsorienterende subjekter, som er virksomme samtidig og bidrager til betydningsdannelsen i den fortællende litteratur. En tilsyneladende objektiv virkelighed kan pludselig vise sig snarere at være udtryk for en karakters forvrængede verdenssyn, ligesom en epistemisk kommentar, som vi i første omgang er tilbøjelige til at tilskrive en fortæller, kan vise sig at være udtryk for protagonistens mentale virksomhed, mening eller tanke.

Når vi således har oplevelsen af at være fulgt igennem et fortalt forløb af en alvidende, altseende fortæller, viser det sig måske snarere, at en mangfoldighed af karakterer ligeledes er kommet til orde. Ligesom Paul Hahrt og hans gangstativ putter de sig blot $\mathrm{i}$ adjektiver, indirekte, indre monologer og 
bortabstraherede synsvinkler. En skærpet opmærksomhed på disse strukturer kan således bevidstgøre os om en semantisk dybde i de ellers tilsyneladende legende simple klassiske fortællestrukturer.4 $\mathrm{Og}$ måske forklare, hvorfor vi bliver ved at vende tilbage til dem.

\section{Noter}

I. Der vil selvfølgelig kunne findes mange undtagelser for disse regler; man kan nemt forestille sig fortællinger, som opstår i fortælleøjeblikket, som en slags improvisationer m.v. På samme måde kan en fortælling på baggrund af en virkelig hændelse godt have elementer, der ligger uden for afsenderens rækkevidde.

2. Brandt antyder noget sådant, når han måler graden af empati i stemmeføringens "temperatur" (jf. fx Brandt: 200I: I).

3. Lignende fortællestrukturer finder vi i tegneserien Steen og Stoffer (Bill Watterson), eller i amerikanske film som Fight Club (Fincher 1999), Den Sjette Sans (Shyamalan 1999), The Others (Amenábar 200I). Også her spiller fortællingen på spændingen imellem, hvad der tilsyneladende er en "objektiv" skildring "udefra", men viser sig at være en "subjektiv" skildring "indefra".

4. Dette er præcis James Woods pointe i artiklen "The Unwinding Stair. Can literature be simple?". Han argumenterer for, at den moderne litteratur har mistet enkelthedens "mødom" $i$ sin stræben efter at være "Sand Kunst". Den traditionelle fortællestil, vi finder hos $\mathrm{fx}$ Tolstoj, Tjekhov og Verga, finder han derimod på en gang enkel og let, mens den samtidigt besidder en betydningsmæssig dybde gennem fortællestrukturer som dem, jeg har beskæftiget mig med i denne fremstilling.

\section{Litteratur}

Adolphsen, Peter: Små Historier, Samleren, Århus 1996. Adolphsen, Peter: Små Historier 2, Samleren, Århus 2000. Brandt, Per Aage: "Fortælling og Sprog", http://www. hum.au.dk/semiotics/docs/epub/

arc/paab/foSpr/FortSpr.html, Center for Semiotik, Aarhus Universitet 200I.

Brandt, Per Aage: "From Gesture to Theatricality - On Enounciation and The Art of Being Visible", http://www.hum.au.dk/semiotics/docs/epub/arc/paab/t heat/ theatricality.hml, Center for Semiotik, Aarhus Universitet 2000 .

Bulgakov, Mikhail: Skabnesvangre $\mathbb{E g}$, Husets Forlag/S.O.L., Århus 1989.

De Maupassant, Guy: "Smykket", Samlede Varker, bind 2, Kbh. 1903-I2.

Dostoevskij, Fjodor M: Rodion Raskolnikov, Bind I + II, H. Hirschsprungs Forlag, Kbh. I952.

Dostojevskij, Fjodor M: Dobbeltgangeren. En Petersborger Digtning, Gyldendals Klassikere, Viborg 1996.

Fleischman, Suzanne: Tense and Narrativity. From Medieval Performance to Modern Fiction, University of Texas Press, Austin 1990.

Gogol, Nikolaj: Kappen, Selskabet Bogvennerne, Carit Andersens Forlag, u. år.

Jahn, Manfred: "More aspects of Focalization: Refinements and Applications",

http://www.uni-koeln.de/ ameo2/jahng9b.htm, 1999.

Jahn, Manfred: "Stanley Fish and the Constructivist Basis of Postclassical Narratology". Reitz, Bernhard; Rieuwerts, Sigrid, eds.: Aglistentag 1999 Mainz: Proceedings. 2000. Saramago, José: En Fortelling om Blindhed, Samlerens Bogklub, Danmark 1999.

Solsjenitsyn, Alexander: En dag i Ivan Denisovitjs Liv, Gyldendal 1963.

Talmy, Leonard: Toward a Cognitive Semantics. Vol. I: Concept Structuring Systems, MIT Press, London 2000a.

Talmy, Leonard: Toward a Cognitive Semantics. Vol. II: Typology and Process in Concept Structuring, MIT Press, London 2ooob.

Tjekhov, Anton: "Skripka Rotsjil'da", I: Polnoe Sobranie Cotjinenij i Pisem, bind 8, side 297-305, Nayka, Moskva I977.

Tolstoj, Lev: “Tre Dødsfald”, I: Sbornik No 1, Slavisk Institut, Aarhus Universitet 1997.

Wood, James: "The Unwinding Stair. Can literature be simple?”, I: The New Republic, side 25-30, Washington march 2003. 